\title{
Effects of sowing native herbaceous species on the post-fire recovery in a heathland
}

\author{
I. Fernández-Abascal, R. Tárrega *, E. Luis-Calabuig, E. Marcos \\ Area de Ecología, Facultad de Ciencias Biológicas y Ambientales, Universidad de León, 24071 León, Spain
}

Received 23 July 2002; accepted 27 February 2003

\begin{abstract}
Erica australis heathlands in León province (NW Spain) have high resilience to disturbances and their post-fire recovery is very fast. The risk of soil erosion is high in the first few months after fire. The aim of this study is to investigate the effects on post-fire succession of sowing grass (Agrostis capillaris and Festuca rubra) and legume (Lotus corniculatus) seeds in a heathland burned by a summer wildfire, and to determine the most suitable native herbaceous species combination for protecting the soil in the first few phases of recovery. Fifteen permanent $4 \mathrm{~m}^{2}$ plots are established in the burned area; four treatments and a control (unsown) are applied, each with three replicates. Three similar unburned plots are also considered (unburned control). Total cover is significantly higher in the sown plots in relation to the control in the first few months after sowing, but there are no differences after 18 months. Lotus corniculatus appears only in the first year and has no effect on the total cover. F. rubra appears earlier than Agrostis capillaris, but decreases significantly in cover after 18 months. Shrub species have the highest cover in the control plots and the lowest in the Agrostis plots. The correspondence analysis shows that the trend for vegetation in all plots reaches similar species composition by the time of final sampling. The last sampling of sown plots shows greater similarity to the control plots than the sampling of these plots within the first year. The fast initial growth of F. rubra, together with its decrease and subsequent low cover from the second year, make it more preferable than Agrostis capillaris for purposes of soil protection. However, additional research, both species- and site-specific, is necessary, as different responses due to different post-fire conditions and pre-fire species composition can have important implications on community dynamics.
\end{abstract}

(c) 2003 Éditions scientifiques et médicales Elsevier SAS. All rights reserved.

Keywords: Agrostis capillaris; Festuca rubra; Heathland; Post-fire seeding; Revegetation; Succession; Wildfire

\section{Introduction}

For thousands of years, fire has been an ecological factor, which has patterned the landscape in many areas of the Earth, and particularly in those with a Mediterranean climate (Naveh, 1974, 1999). However, in the last few decades, the number of fires and the total area burned in the European Mediterranean have increased considerably (Moreno and Vallejo, 1999; Pausas and Vallejo, 1999). Forest fires are presently one of the most serious threats to ecosystem conservation, not only because of vegetation destruction but also because of the soil loss, which seriously jeopardises possible recovery. The dominant plants of most Mediterranean shrublands, like Erica australis heathlands, can resprout vegetatively after a fire; so recovery is by autosuccession and quite

\footnotetext{
* Corresponding author

E-mail address: degelc@unileon.es (R. Tárrega).
}

fast (Naveh, 1974; Luis et al., 1987; Trabaud, 1987; Calvo et al., 1998; Vallejo and Alloza, 1998). The main risk of erosion loss is therefore only in the first few stages after fire (DiazFierros et al., 1990; Marcos et al., 2000).

One of the most commonly used methods to reduce erosion losses is to sow herbaceous species to protect the soil, especially during the first year after fire (Ruby, 1989). Lolium multiflorum or a mixture of Poaceae and Leguminosae plants have been widely used; the effectiveness of these treatments is low to moderate, according to the environmental conditions of the burned and sown areas, and is particularly dependent on post-sowing meteorological conditions (Miles et al., 1989). Moreover, Taskey et al. (1989) discovered that the use of Lolium is not effective because, although it increases total soil coverage, it reduces spontaneous vegetation recovery and increases erosion. Those who disparage this technique state that sown vegetation interferes with natural recolonisation and may have long-term effects on post-fire vegetation 
composition and structure (Conard et al., 1995). Keeley (1998) found that the cover of sown species was insignificant in comparison with those recovering naturally in burned areas in California. However, other studies (Bautista et al., 1997; Vallejo and Alloza, 1998) showed that sowing herbaceous species caused an initial increase in cover and did not modify the regeneration of native plant communities.

The aim of this study is to determine whether sowing herbaceous species native to the area produces an increase in plant cover in the first few stages of regeneration after a fire. We also investigate the dynamics of natural plant recovery, since the growth of seeded species is hypothesised to reduce the growth of naturally regenerating species. To test this hypothesis, the responses of two perennial Poaceae, Agrostis capillaris and Festuca rubra, are compared. We also aim to determine whether the presence of the Leguminous species, Lotus corniculatus, causes any change in the patterns of recovery. We test the hypothesis on whether this species can enhance the growth capacity of the other plants by increasing nitrogen in the soil.

\section{Materials and methods}

The study was conducted in a heathland dominated by $E$. australis and Erica umbellata in the province of León (NW Spain), M.T.U. co-ordinates: 30TTN7631. There was no slope and the altitude was $1100 \mathrm{~m}$ above sea level. The soil was of cambisol type with siliceous materials, which is highly prone to erosion relative to the substrate (del Val, 1995). The climate was cool, temperate Mediterranean; the mean temperature in the coldest month (January) was $2.5^{\circ} \mathrm{C}$ and in the warmest month (July) $18.7^{\circ} \mathrm{C}$; annual precipitation was $736 \mathrm{~mm}$, with a dry period only in summer (Ministerio de Agricultura, 1980). The climax vegetation was a Quercus pyrenaica forest (Luzulo forsteri-Querceto pyrenaicae sigmetum, Rivas-Martinez, 1987).

The area was burned by a wildfire on 16th September 1995, and sowing was completed on 25th October 1995. Fifteen permanent $4 \mathrm{~m}^{2}$ plots were established in the burned area; four treatments and an unsown control, each replicated three times. The treatments were randomly assigned to the plots, but without repetition in the same row or column. Seed quantity was estimated by weight in order to have 20,000 seeds per square meter in each plot, equally divided amongst the species assigned to each treatment. The four treatments were as follows: seeding plots with (a) $F$. rubra $\left(25.22 \mathrm{~g} / \mathrm{m}^{2}\right)$; (b) F. rubra $\left(12.61 \mathrm{~g} / \mathrm{m}^{2}\right)$ and Lotus corniculatus $(13.70$ $\left.\mathrm{g} / \mathrm{m}^{2}\right)$; (c) Agrostis capillaris $\left(2.04 \mathrm{~g} / \mathrm{m}^{2}\right)$; and (d) Agrostis capillaris $\left(1.02 \mathrm{~g} / \mathrm{m}^{2}\right.$ ) and Lotus corniculatus $\left(13.70 \mathrm{~g} / \mathrm{m}^{2}\right)$. These herbs were commercial varieties with a high germination index.

Samplings were carried out 1, 3, 6, 8, 11, 14, 16, 18, 20, 23, 32 and 44 months after sowing. The cover percentage of all the plant species present was visually estimated. A square sampling unit measuring $0.5 \mathrm{~m}$ on each side was used. Four units, located in the central $1 \mathrm{~m}^{2}$ of each $4 \mathrm{~m}^{2}$ plot, were analysed. The mean of the four units from each plot and the sampling period were used for subsequent analysis. Three 4 $\mathrm{m}^{2}$ plots, selected at random, were also sampled in the unburned neighbouring area, in June 1997, in order to have controls of conditions before the fire (unburned control).

The results for total cover of sown species, cover of each sown species, and cover of woody and herbaceous species (sown + naturally occurring) were compared (after arc-sine transformation) using analysis of variance. When the changes over time in the same plot were considered, a repeated measures analysis of variance was used. The Scheffetest (Scheffe, 1959) was applied for a comparison between pairs when ANOVA was significant $(P<0.05)$. Sample normality was checked beforehand using the David test (David et al., 1954); the homogeneity of variances with the Cochran test (Cochran, 1941).

A correspondence analysis was used in order to compare the floristic composition of the plots at each time of sampling (CANOCO Program, Ter Braak, 1991). In this case, only the mean values of the replicates for each treatment obtained from the June samples were included (in order to eliminate phenological variation). Species which appeared only once were ignored.

\section{Results}

On comparing total cover values, significant differences $\left(F_{4,10}=61.43, P<0.005\right)$ were observed between the sown and unsown plots from the first sampling (November 1995, 1 month after sowing) and these differences remained until June 1996 Fig. 1. During this period, cover was greater in the plots, where $F$. rubra (alone or with Lotus corniculatus) was sown than in those sown with Agrostis capillaris, but these differences were not statistically significant. In samplings from September to December 1996, differences between the total cover of the unsown plots and those sown with $F$. rubra were still detectable, but not between the former and those sown with Agrostis capillaris. From the February 1997 sampling, no significant differences could be detected, and in the last sampling (June 99) there was even greater cover in the control plots than in the sown ones. It was during these final stages that the unsown species in the $F$. rubra plots showed the greatest contribution to cover, in comparison with the Agrostis capillaris plots. No differences were seen in the plots sown with Lotus corniculatus, except in the first sampling when a greater cover in the plot sown with Agrostis capillaris and Lotus corniculatus was observed than in those sown only with Agrostis capillaris.

The very small contribution made by Lotus corniculatus, which only appeared in the initial stage and never at values above 10\%, is shown in Fig. 2. This leguminous species did not contribute to significant differences in cover by the grasses, whether they were sown with or without it, despite differences in sowing densities. The cover of $F$. rubra was significantly greater $\left(F_{3,8}=4.55, P<0.05\right)$ than that of Agrostis capillaris until April 1996 (6 months after sowing). 

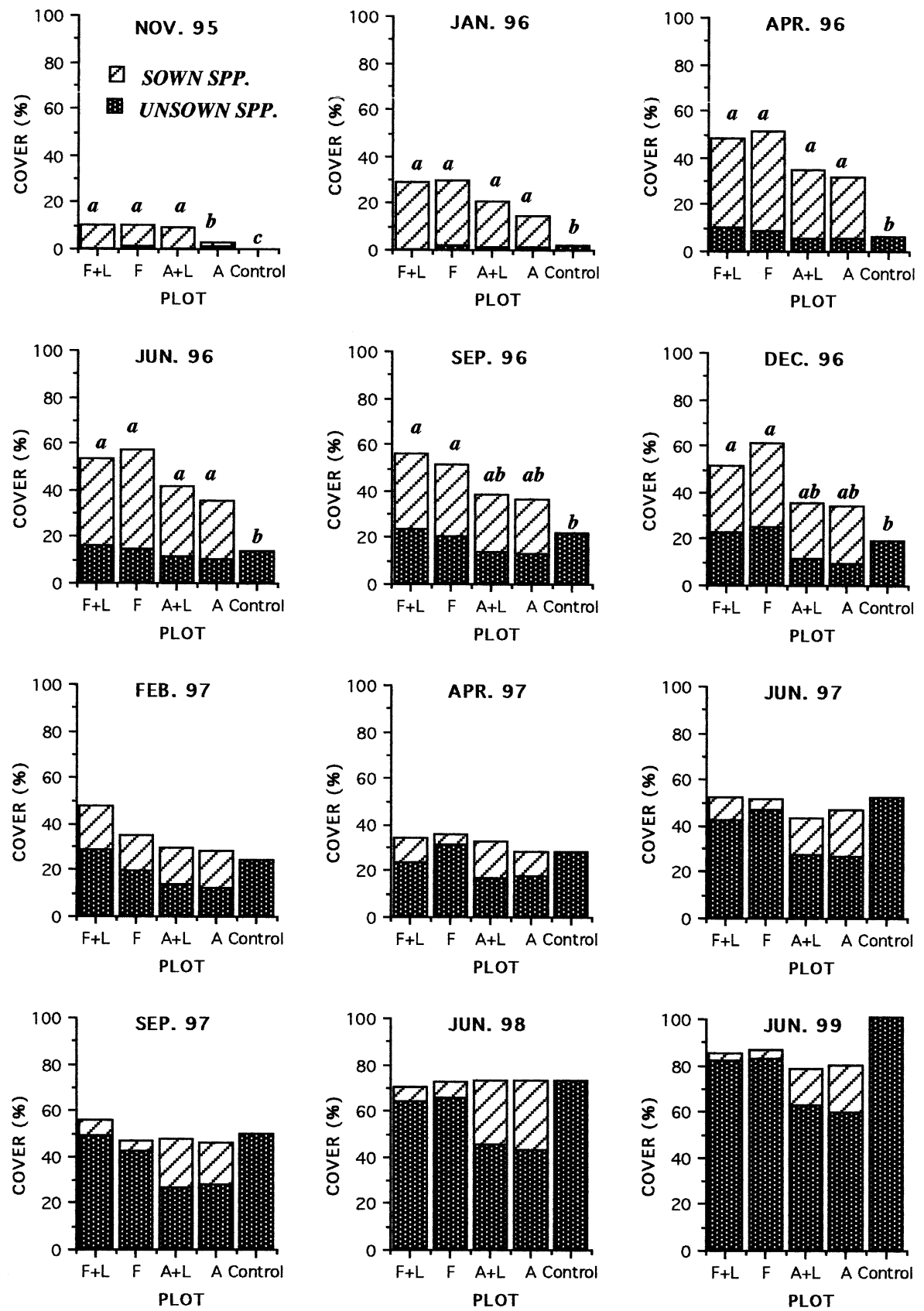

Fig. 1. Mean cover of sown and unsown species in the burned plots during the study period (F+L, plots sown with F. rubra and Lotus corniculatus; F, plots sown with F. rubra; A + L, plots sown with Agrostis capillaris and Lotus corniculatus; A, plots sown with Agrostis capillaris; Control, unsown plots. Different letters above the bars in the same graph indicate significant differences in total cover by Scheffe-test).

From June 1997, the mean value for cover of Agrostis capillaris was larger than that of F. rubra, but the difference between the values was statistically significant only in the last two samplings (June 1998, $F_{3,8}=9.46, P<0.01$, and June $\left.1999, F_{3,8}=18.61, P<0.001\right)$. When the cover of each grass species over the course of time in one plot was compared (using analysis of variance of repeated measures, but considering only the June samplings to eliminate any phenological variability) differences were detected in the F. rubra values (significantly higher at 8 months, in June 1996, than in later years, $\left.F_{2,9}=44.08, P<0.001\right)$ but not in those of Agrostis capillaris $\left(F_{2,9}=2.27, P=0.18\right)$.
Sowing did not determine differences in the natural recovery of the woody species in the first stages. However, from June 1997 (20 months after sowing) woody cover was significantly lower in the plots sown with Agrostis capillaris than in the unsown ones $\left(F_{4,10}=6.40, P<0.01\right)$, and the differences remained in the last sampling Table 1, Fig. 3 . The cover by herbaceous species (considering both sown and naturally occurring species) was significantly higher in the sown plots than in the control ones $\left(F_{4,10}=11.68, P<0.001\right)$ until December 1996 (14 months after sowing). Later, the herbaceous cover continued to be lower in the control plots, but was statistically significant only in June $1998\left(F_{4,10}=\right.$ 

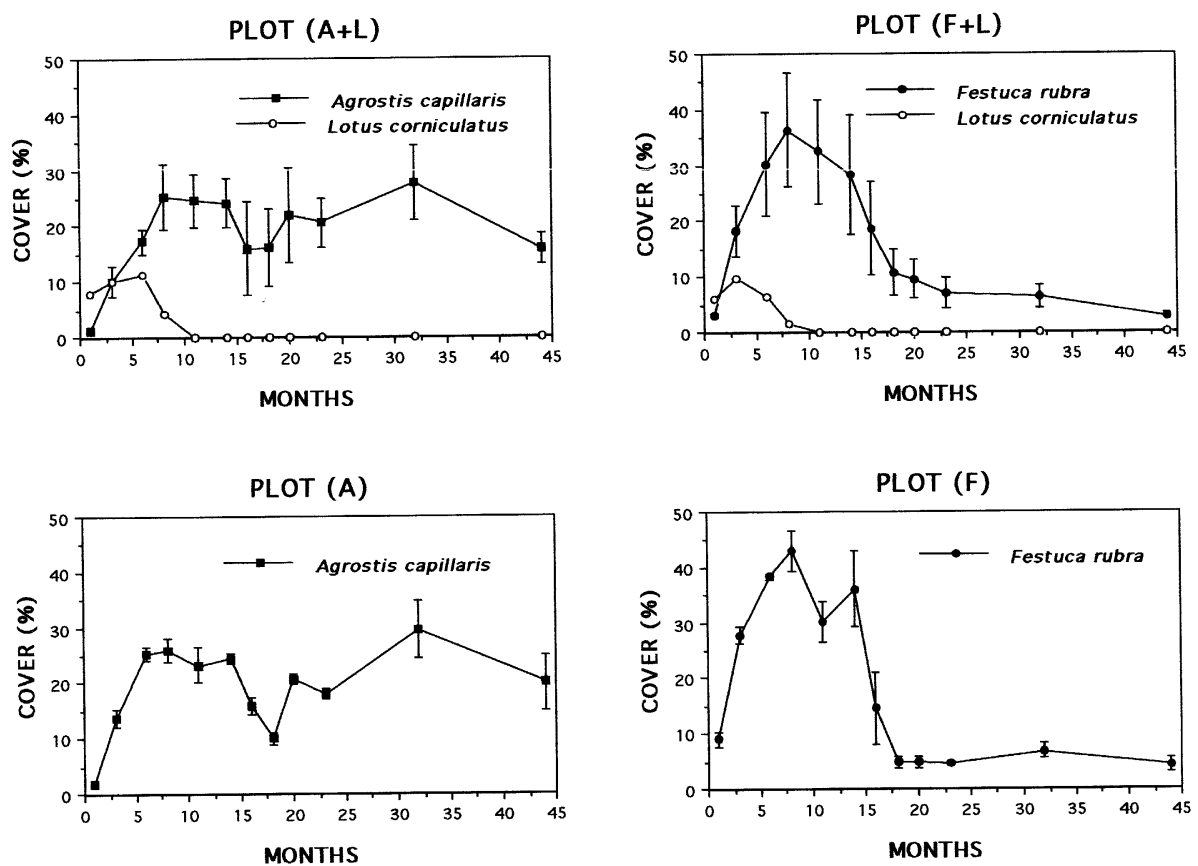

Fig. 2. Mean cover (and standard error) of sown species in the plots during the study period (A + L, plots sown with Agrostis capillaris and Lotus corniculatus; F + L, plots sown with F. rubra and Lotus corniculatus; A, plots sown with Agrostis capillaris; F, plots sown with F. rubra).

$11.11, P=0.001)$. Unsown herbaceous species had low cover values, similar in all the plots (Table 1).

In an overall comparison of results using the analyses of correspondence, 21 samplings (five plot types $\times 4$ years, and the unburned plot) and 20 species were considered (species appearing only in one sampling were excluded). On the first two axes of the ordination diagram Fig. 4a , the separation in terms of the grass species sown was observed, but no influence of Lotus corniculatus was apparent. In addition, considering each treatment, a clear temporal trend could also be appreciated Fig. 4b. Almost all the samplings from the plots with $F$. rubra were situated towards the positive part of the first axis. The greatest differences were detected in the samplings carried out in the year of the fire (June 1996), which were at the positive end. Axis II separated the plots sown with Agrostis capillaris towards the negative part, from the unburned control area, associated with E. australis and $E$. umbellata, at the positive end. In the control plots (not sown) the temporal trend was also observed in terms of this second axis, with progressively increasing similarity to the unburned plot; however, in 4 years since the fire, recovery was not complete. The greatest similarity of the control unsown plots

Table 1

Mean cover values (\%) of the most frequent species (sown and unsown) in the June samplings (C, control unsown plots; AL, plots sown with Agrostis capillaris and Lotus corniculatus; A, plots sown with Agrostis capillaris; FL, plots sown with F. rubra and Lotus corniculatus; F, plots sown with F. rubra; UB, unburned plots)

\begin{tabular}{|c|c|c|c|c|c|c|c|c|c|c|c|c|c|c|c|c|c|c|c|c|c|}
\hline & \multicolumn{5}{|c|}{ June 1996} & \multicolumn{5}{|c|}{ June 1997} & \multicolumn{5}{|c|}{ June 1998} & \multicolumn{5}{|c|}{ June 1999} & \multirow[t]{2}{*}{ UB } \\
\hline & $\mathrm{C}$ & $\mathrm{AL}$ & A & FL & $\mathrm{F}$ & $\mathrm{C}$ & $\mathrm{AL}$ & A & FL & $\mathrm{F}$ & $\mathrm{C}$ & $\mathrm{AL}$ & A & FL & $\mathrm{F}$ & $\mathrm{C}$ & $\mathrm{AL}$ & A & FL & $\mathrm{F}$ & \\
\hline \multicolumn{22}{|l|}{ Shrub species } \\
\hline Erica australis & 0.5 & 0.1 & 0.1 & 0.1 & 0.1 & 3.5 & 0.3 & 0.1 & 0.9 & 0.1 & 6.3 & 0.7 & 1.5 & 3.7 & - & 8.8 & 1.3 & 2.5 & 8.8 & 0.3 & 53.3 \\
\hline Erica umbellata & 0.7 & 0.6 & 0.2 & 0.6 & 0.5 & 7.4 & 0.7 & 0.3 & 2.2 & 1.0 & 19.0 & 2.5 & 0.7 & 3.2 & 2.1 & 37.5 & 3.4 & 2.8 & 8.2 & 5.8 & 47.9 \\
\hline Genistella tridentata & 5.3 & 3.2 & 3.8 & 3.6 & 4.8 & 22.7 & 12.5 & 11.7 & 12.9 & 22.2 & 22.9 & 17.2 & 17.2 & 15.8 & 29.3 & 28.3 & 28.3 & 26.0 & 25.6 & 37.5 & 16.3 \\
\hline Halimium alyssoides & 2.6 & 2.9 & 3.5 & 8.4 & 4.6 & 10.2 & 9.0 & 7.6 & 20.0 & 12.3 & 14.2 & 13.9 & 13.3 & 27.9 & 15.2 & 19.4 & 23.3 & 20.4 & 31.7 & 24.2 & 13.8 \\
\hline \multicolumn{22}{|l|}{ Grass species } \\
\hline Agrostis capillaris & - & 25.3 & 30.0 & - & - & 0.5 & 21.8 & 20.7 & - & - & 1.3 & 27.8 & 29.6 & 1.3 & 1.6 & 0.9 & 15.8 & 20.0 & 0.5 & 0.7 & - \\
\hline Aira caryophyllea & 3.2 & 3.7 & 1.4 & 1.0 & 1.4 & 5.2 & 2.7 & 2.9 & 2.0 & 3.0 & 5.5 & 5.5 & 3.2 & 3.3 & 3.8 & 2.0 & 1.6 & 1.8 & 1.2 & 2.3 & - \\
\hline Avenula marginata & 0.1 & - & 0.1 & 0.2 & 0.1 & 0.3 & 0.1 & 0.9 & 0.2 & 0.6 & 1.4 & 0.3 & 3.0 & 0.7 & 2.1 & 0.9 & 0.4 & 3.3 & 1.8 & 3.3 & 0.2 \\
\hline Festuca rubra & - & 2.9 & - & 36.4 & 42.9 & 0.6 & - & - & 9.6 & 4.8 & - & - & - & 6.5 & 6.8 & 1.1 & - & - & 2.8 & 4.3 & - \\
\hline Luzula lactea & - & - & 0.2 & - & 1.7 & - & - & 0.4 & - & 2.5 & - & - & 0.7 & - & 2.2 & - & - & 0.4 & - & 2.3 & - \\
\hline \multicolumn{22}{|l|}{ Other herb. spp. } \\
\hline Arnoseris minima & 0.1 & - & - & 0.1 & 0.1 & 0.1 & 0.5 & 0.4 & 0.6 & 0.8 & 0.1 & 1.8 & 1.2 & 1.2 & 3.4 & 0.1 & 0.5 & 0.7 & 0.3 & 0.7 & - \\
\hline Asphodelus albus & - & 0.5 & 0.2 & 0.5 & 0.5 & 0.1 & 0.4 & 0.6 & 0.7 & 1.4 & 0.2 & 2.0 & 0.6 & 1.5 & 1.8 & 0.3 & 2.6 & 0.7 & 0.7 & 2.3 & 0.5 \\
\hline Tuberaria globularifolia & 0.1 & - & - & 0.3 & - & 0.7 & 0.3 & 0.2 & 1.5 & 0.8 & 1.3 & 0.8 & 0.3 & 2.7 & 2.3 & 1.2 & 0.7 & 0.8 & 3.0 & 2.5 & - \\
\hline
\end{tabular}



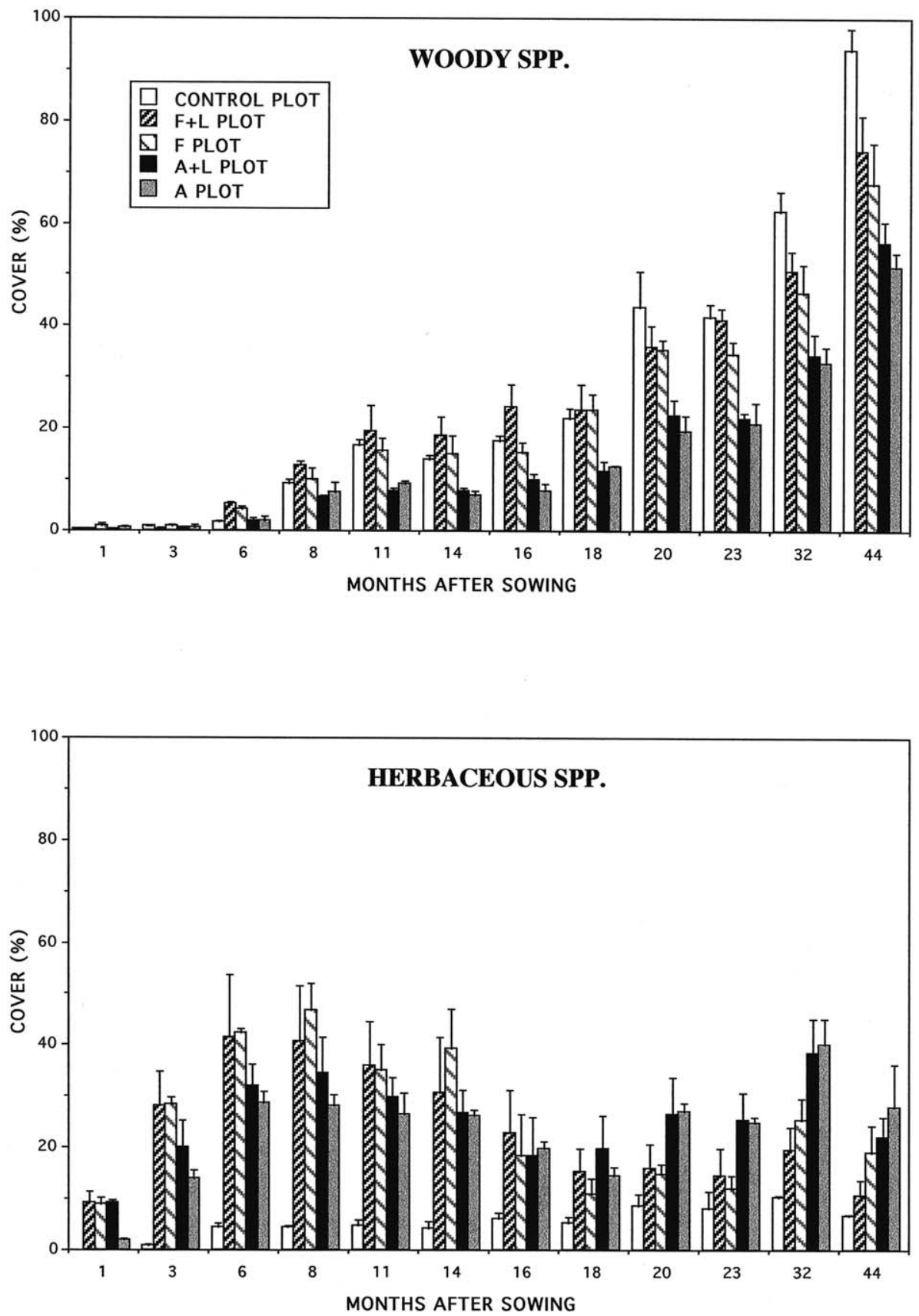

Fig. 3. Mean cover (and standard error) of shrub and herbaceous species (sown and unsown) in the burned plots during the study period (Control, unsown plots; F + L, plots sown with F. rubra and Lotus corniculatus; F, plots sown with F. rubra; A + L, plots sown with Agrostis capillaris and Lotus corniculatus; A, plots sown with Agrostis capillaris).

to the unburned ones was mainly due to the greater cover of the two dominant Ericaceae, which recovered more slowly in the sown plots. Recovery of the other two woody species, Genistella tridentata and Halimium alyssoides, also abundant although less so in that area, was similar in all the plots. This was shown by their location close to the origin of the co-ordinates in the species ordination. The rapid recovery of E. umbellata (an obligate seeder) in these plots was worth mentioning Table 1. By the fourth year, the cover of this species was still significantly greater in the unsown control plots (more than 35\%) than in the sown ones (3-8\%), al- though it did not attain the values of the unburned area (48\%). E. australis recovered more slowly (cover was below $10 \%$ in all burnt plots after 4 years) despite being a resprouter and having cover exceeding $50 \%$ in the unburned area.

\section{Discussion}

The fast initial growth of $F$. rubra, together with its decrease and subsequent low cover from the second year, made it more preferable than Agrostis capillaris for purposes 


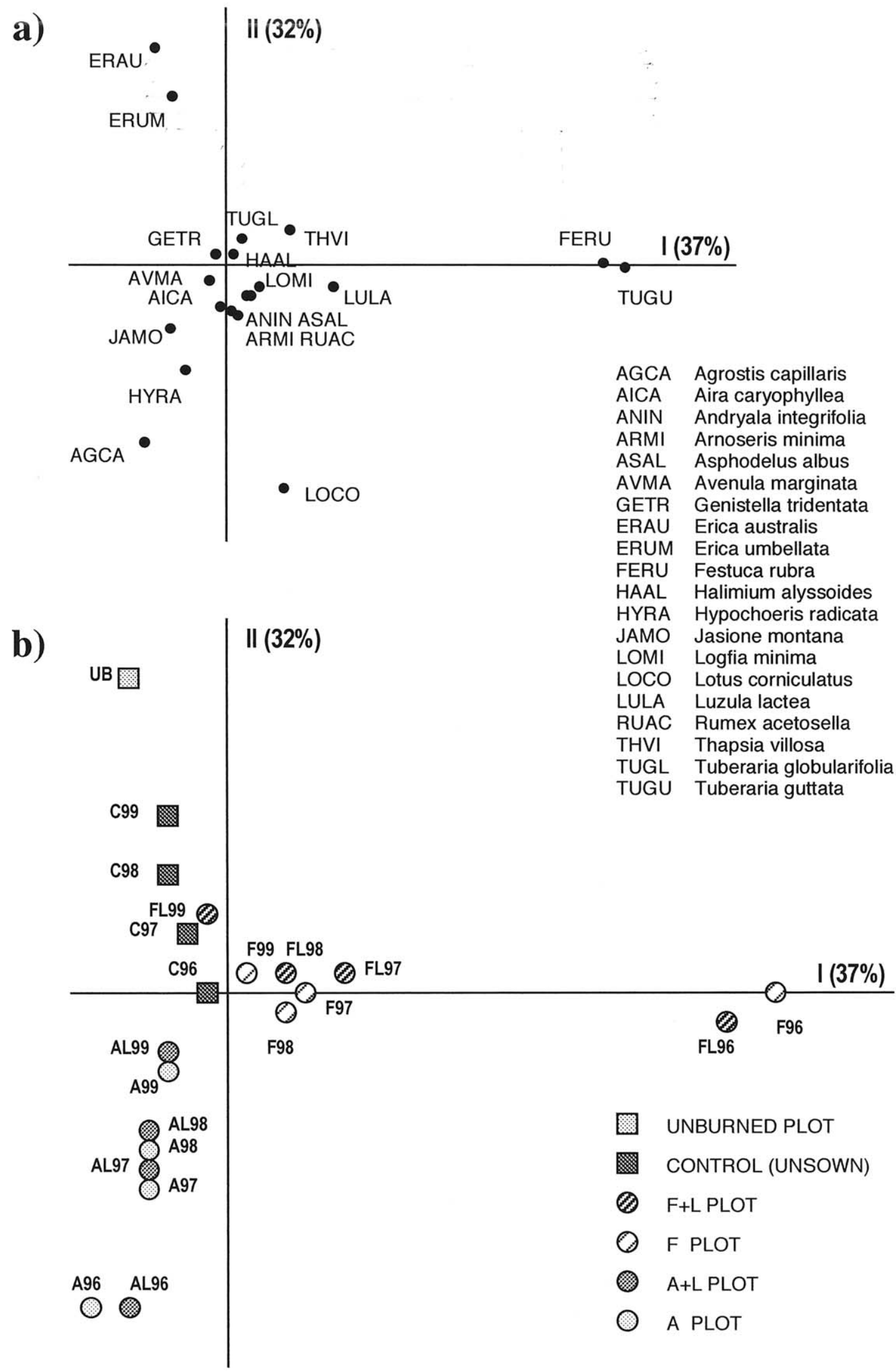

Fig. 4. Situation in the plane defined by the first two axes of the correspondence analysis (only the June samplings were considered). (a) Species ordination. (b) Ordination of sampling data (UB, unburned plots; C, control unsown plots; F+ L, plots sown with F. rubra and Lotus corniculatus; F, plots sown with F. rubra; A + L, plots sown with Agrostis capillaris and Lotus corniculatus; A, plots sown with Agrostis capillaris). 
of soil protection. Agrostis capillaris cover values were lower at the beginning of the experiment and were maintained throughout the study period. The reasons for this different response were not clear. Both species were rhizomatous perennials and usually appeared in these areas, although with low cover when shrubs were dominant (both species were in the unsown control plots). The different behaviour of the two grasses also had a different effect on natural regeneration. The plots with Agrostis capillaris had significantly lower cover by the woody species characteristic of the area, and the differences remained until the fourth year, whilst $F$. rubra did not interfere with the recovery of the native vegetation to the same extent. Lotus corniculatus only appeared in the first few months and apparently had no influence either on the response of the sown species or on the natural vegetation, since no significant differences were detected in total cover due to the presence of this species.

However, the results can vary according to the meteorological conditions after sowing. The latter was shown by comparing the results of this study with those obtained in a heathland of similar characteristics experimentally burned in summer, and sown with the same herbaceous species as in the present study in the following spring (March). Abnormally adverse meteorological conditions that year (March was very warm but April and May were very cold and dry) resulted in a very low success of sown herbaceous species (FernándezAbascal et al., 1998).

In a post-fire restoration study in the east of Spain (Bautista et al., 1997; Vallejo and Alloza, 1998), a mixture of herbaceous species was sown and higher cover values were found than in the control areas. This difference disappeared in the first spring after seeding in the subhumid plots (almost 1 year after the fire) and only remained detectable in the semiarid plots. It could be expected from these results that in more humid conditions, as in our study area, the cover in the sown plots and in the controls would reach similar values more quickly. However, the differences were still significant 14 months after sowing. On the other hand, both sown species remained, although in different proportions, at the end of the study period, whilst in the previously mentioned study, 4 years after the treatment, only a few individuals of the sown species remained.

Temporal changes in floristic composition indicated a tendency towards recovery of the original composition, with E. australis and E. umbellata dominating. The interference of the sown species, and particularly Agrostis capillaris, seemed to be related to the regeneration strategy of the woody species, since the greatest differences from the unsown control plots were in the cover of E. umbellata, which could only recover from seed in these areas. The reason for the more rapid recovery response of this species in comparison with the resprouter E. australis was not clear, and did not conform to that recorded in burned heathland of similar characteristics (Calvo et al., 1998). On comparing two congeneric species from Western Australia, much higher initial growth was found in the seeder species than in the resprouter one, but only when recruiting from seeds; the older resprouter plants had a faster initial recover presumably because of their greater root reserves (Hansen et al., 1991; Bowen and Pate, 1993). On the other hand, Conard et al. (1995) found that seeded grass competed with the spontaneous herbaceous species, but not with the chaparral shrubs in Southern California. However, unsown herbs had low cover in the study area, and there were no differences between the sown and control plots Table 1.

Another aspect to be taken into account in the management of burned areas was whether the environmental benefits justified the economic cost of revegetation. In the studies carried out in California, it was found that the contribution of sown species (aerially seeded) was insignificant compared with natural recolonisation (less than 15\%), and did not justify the economic investment (Keeley, 1998). The results obtained in this study with $F$. rubra showed cover values above $40 \%$ in some cases, and with less interference with natural regeneration. However, the dependence of success of seedling establishment on unpredictable post-fire weather conditions must not be overlooked. As previously shown by other authors (Moreno and Vallejo, 1999; Vallejo et al., 2000 ), the priority of post-fire restoration must be concentrated on those areas with an important risk of soil loss by erosion due to the bad natural recovery, which was not the case in the heathland studied. In a similar experimentally burned heathland, Marcos et al. (2000) recorded only slight runoff and sediment removal, mainly due to rapid resprouting of the native vegetation. This would make the cost of revegetation unnecessary in most of these ecosystems. However, given that the area had high potential for substrate erosion (del Val, 1995), it was always useful to know the behaviour of different species to plan suitable programmes for short-term soil protection, in those cases where natural regeneration was slower. Additional research, both speciesand site-specific, was necessary, since different responses due to different post-fire conditions and pre-fire species composition can have important implications on post-fire community dynamics.

\section{References}

Bautista, S., Abad, N., Llovet, J., Bladé, C., Ferran, A., Ponce, J.M., Caturla, R.N., Alloza, J.A., Bellot, J., Vallejo, R., 1997. Siembra de herbáceas y aplicación de mulch para la conservación de suelos afectados por incendios forestales. In: Vallejo, R. (Ed.), La Restauración de la Cubierta Vegetal en la Comunidad Valenciana. Fundación Centro de Estudios Ambientales del Mediterráneo, pp. 395-434.

Bowen, B.J., Pate, J.S., 1993. The significance of root starch in post-fire shoot recovery of the resprouter Stirlingia latifolia $\mathrm{R}$. Br. (Proteaceae). Annals of Botany 72, 7-16.

Calvo, L., Tárrega, R., Luis, L., 1998. Space-time distribution patterns of Erica australis L. subsp. aragonensis (Willk) after experimental burning, cutting and ploughing. Plant Ecology 137, 1-12.

Cochran, W.G., 1941. The distribution of the largest of a set estimated variances as a fraction of their total. Annals of Eugenics 11, 47-61. 
Conard, S.G., Beyers, J.L., Wohlgemuth, P.M., 1995. Impacts of postfire grass seeding on chaparral systems-what we know and where do we go from here. In: Keeley, J.E., Scott, T. (Eds.), Brushfires in California Wildlands: Ecology and Resource Management. Association of Wildland Fire, Fairfield, Washington, pp. 149-161.

David, H.A., Hartley, M.O., Pearson, E.S., 1954. The distribution of the ratio, in a single normal sample of range to standard deviation. Biometrika 41, 482-493.

del Val, J., 1995. Mapa de erosión. Atlas del Medio Natural de la Provincia de León. Instituto Tecnológico Geominero de España, Madrid.

Diaz-Fierros, F., Benito, E., Vega, J.A., Castelao, A., Soto, B., PerezMoreira, R., Taboada, T., 1990. Solute loss and soil erosion in burnt soil from Galicia (NW Spain). In: Goldammer, J.G., Jenkins, M.J. (Eds.), Fire in Ecosystem Dynamics. SPB Academic Publishing, The Hague, pp. 103-116.

Fernández-Abascal, I., Luis, E., Tárrega, R., Valbuena, L., 1998. Five years of recovery after experimental fire in a heathland. Effects of sowing native species. In: Viegas, E.X. (Ed.), Proceedings of the Third International Conference on Forest Fire Research, pp. 1889-1899 Coimbra, Portugal.

Hansen, A., Pate, J.S., Hansen, A.P., 1991. Growth and reproductive performance of a seeder and a resprouter species of Bossiaea as a function of plant age after fire. Annals of Botany 67, 497-509.

Keeley, J.E., 1998. Postfire ecosystem recovery and management: the October 1993 large fire episode in California. In: Moreno, J.M. (Ed.), Large Forest Fires. Backhuys Publishers, Leiden, The Netherlands, pp. 69-90.

Luis, E., Tárrega, R., Zuazua, T., 1987. Shrub responses to experimental fire. First phases of regeneration. Ecologia Mediterranea XIII (4), 155-162.

Marcos, E., Tárrega, R., Luis, E., 2000. Comparative analysis of runoff and sediment yield with a rainfall simulator after experimental fire. Arid Soil Research and Rehabilitation 14, 293-307.

Miles, S.R., Haskins, D.M., Ranken, D.W., 1989. Emergency burn rehabilitation: cost, risk and effectiveness Proceedings of the Symposium on Fire and Watershed Management. USDA General Technical Report PSW-109.

Ministerio de Agricultura, 1980. Caracterización Agroclimática de la Provincia de León. Dirección General de la Producción Agraria, Madrid.
Moreno, J.M., Vallejo, R., 1999. Fire impacts on the ecosystem and restoration: summary of the main findings from the DELFI-fire database Proceedings of International Symposium on Forest Fires: Needs and Innovations Athens, Greece.

Naveh, Z., 1974. Effects of fire in the Mediterranean region. In: Kozlowski, T.T., Ahlgren, C.E. (Eds.), Fire and Ecosystems. Academic Press, New York, pp. 401-434.

Naveh, Z., 1999. The role of fire as an evolutionary and ecological factor on the landscapes and vegetation of Mt. Carmel. Journal of Mediterranean Ecology 1, 11-25.

Pausas, J.G., Vallejo, R., 1999. The role of fire in European Mediterranean ecosystems. In: Chuvieco, E. (Ed.), Remote Sensing of Large Forest Fires in the European Mediterranean Basin. Springer, pp. 3-16.

Rivas-Martinez, S., 1987. Mapa de Series de Vegetación de España. ICONA, Madrid.

Ruby, E.C., 1989. Rationale for seeding grass on the Stanislaus Complex burn Proceedings of the Symposium on Fire and Watershed Management. USDA General Technical Report PSW-109.

Scheffe, H., 1959. The Analysis of Variance. John Wiley and Sons, Inc., New York.

Taskey, R.D., Curtis, C.L., Stone, J., 1989. Wildfire, ryegrass seeding, and watershed rehabilitation. Proceedings of the Symposium on Fire and Watershed Management USDA General Technical Report PSW-109.

Ter Braak, C.J.F., 1991. A FORTRAN program for canonical community ordination by partial detrended canonical correspondence analysis, principal components analysis and redundancy analysis. TNO, Wageningen CANOCO (version 3.12).

Trabaud, L. (Ed.), 1987. The Role of Fire in Ecological Systems. SPB Academic Publishing, The Hague.

Vallejo, R., Alloza, J.A., 1998. The restoration of burned lands: the case of Eastern Spain. In: Moreno, J.M. (Ed.), Large Forest Fires. Backhuys Publishers, Leiden, The Netherlands, pp. 91-108.

Vallejo, R., Bautista, S., Cortina, J., 2000. Restoration for soil protection after disturbances. In: Trabaud, L. (Ed.), Life and Environment in the Mediterranean. WIT Press, Boston, pp. 301-343. 